\title{
THE VIOLENCE AGAINST YEZIDI WOMEN: THE ISLAMIC STATE'S SEXUAL SLAVERY SYSTEM
}

\author{
Beatriz Buarque $^{1}$
}

\begin{abstract}
Since August 2014, thousands of Yezidi women and girls have been taken away from their communities and have received brutal treatment from the so-called organization Islamic State, including rape and the selling of them as goods. This kind of violence has been occurring for almost two years, but only recently the world became aware of it as some of the girls managed to flee from the captivity and testified the brutal treatment they received under the hands of the extremist group. This article intends to throw some light in the sexual slavery system established by the Islamic State focused on Yezidi women and makes an effort to understand why governments and security organizations have failed to extinguish this kind of gender violence that has made millions of victims along these years.
\end{abstract}

Keywords: sexual slavery - Islamic State - rape Yezidi women
Resumo: Desde agosto de 2014, milhares de mulheres e meninas Yezidi são tiradas de suas comunidades, estupradas e vendidas como mercadoria pelo autoproclamado Estado Islâmico. Esse tipo de violência já dura pelo menos dois anos, mas apenas recentemente o mundo tomou conhecimento da forma pela qual essas mulheres são tratadas pelo grupo extremista. O presente artigo se propõe a lançar luz sobre o sistema de escravidão sexual estabelecido pelo Estado Islâmico, buscando compreender porque o sistema foca principalmente na comunidade Yezidi. O artigo também tenta compreender por que governos e organizações de segurança têm falhado na extinção desse tipo de violência de gênero que tem feito milhões de vítimas ao longo dos anos.

Palavras-chave: escravidão sexual - Estado Islâmico - estupro - mulheres Yezidi

\section{Introduction}

Yezidism is the religion of a minority found mainly in Iraq, but with followers in Syria, Armenia and other countries. Due to the historical persecution Yezidis have suffered, they used to live in the mountains of northern Iraq to protect themselves against Muslims who accused them of being Devil worshippers.

According to the NGO Yazda², the Yezidi population living in Iraq prior to August, 2014 (when the Islamic State conquered important regions in the country) was about six hundred thousand. The organization estimates about $25 \%$ of them left the country after the Islamic State occupation. Yazda estimates five thousand Yezidis may have been killed in Sinjar alone, a Yezidi-inhabited Iraq district in the mountains of North Iraq

In August 2014, when the so-called Islamic State started conquering areas near Sinjar, thousands of Yezidis managed to flee from there prior to its arrival. However, thousands of

\footnotetext{
${ }^{1}$ Beatriz Buarque é jornalista formada pela UFRJ, com participação em congressos sobre a História da Midiologia. Trabalha há quase dez anos na TV Globo e atualmente é voluntária da ONG Free Yezidi Foundation.

${ }^{2}$ Yazda Organization is an NGO that helps Yezidi people in Northern Iraq, northeastern Syria and those living in the US. It also provides information to researchers interested in the Yezidi situation.
} 
families were unable to do so. Yazda estimates that about 5.838 people were abducted during the invasion. Among those left behind, testimonies are almost the same as those Amnesty International presented in its report Escape from Hell (2014): younger women were separated from their parents and exposed to all kinds of sexual violence.

A report from the Assyrian International News Agency is even more accurate in describing the siege of Mount Sinjar:

F says she was driven to the Iraqi city of Mosul some six hours away, where they
herded them into the Galaxy Wedding Hall. Other groups of women and girls were
taken to a palace from the Saddam Hussein era, the Badoosh prison compound
and the Directory of Youth building in Mosul, recent escapees said. And in
addition to Mosul, women were herded into elementary schools and municipal
buildings in the Iraqi towns of Tal Afar, Solah, Ba'aj and Sinjar City. They would
be held in confinement, some for days, and some for months. Then, inevitably,
they were loaded into the same fleet of buses again before being sent in smaller
groups to Syria or to other locations inside Iraq, where they were bought and
sold for sex. (Callimachi, 2015: 02)

Recently, an American researcher who has worked for Yazda in Iraq revealed that around 2.400 people - including women and even men - managed to escape from IS captivity from 2014 until now. Regarding sexual slavery, the Yezidi community believes more than 1.500 women and girls remain in captivity.

Amnesty Report believes up to 300 abducted women and children managed to escape from IS until the end of 2014. One possible explanation of the increase in the number of escapees might be linked to a kind of rescue market that has emerged around the captives. By interviewing board members of some Foundations ${ }^{3}$ that help Yezidis in Iraq, I was able to understand more about the rescue operation. Steve Maman, a Jew well-known for his efforts to rescue Yezidi women and girls, told me, in details, how that process works:

We realized the amount of women that have been taken around the month of November,
December, January 2015, there were lots of news report about women that were been
sold in the market, young girls been sold and the sex slavery and all that, and we
started to look at ideas on how to put together a team in order to be able to negotiate
the release of those girls. Until today, we have negotiated the release of 140 women
and girls from the point where they were held sexual slaves.

According to Steve Maman, there are two types of negotiation: in one type, he gives money to strugglers - Iraqi men who know captivities' location and have some information on soldiers' fragilities, which enables him to rescue women and girls; in the other type, families are wealthy enough to pay for the rescues. Despite the fact this operation is based on negotiations, Mr. Maman is emphatic in his defense of not negotiating with Islamic State soldiers.

\footnotetext{
${ }^{3}$ One of these Foundations is CYCI, The Liberation of Christian and Yazidi Children of Iraq, founded by Steve Maman. CYCI has rescued Yezidi women and girls through different ways with the same agent: a struggler a person who knows captivities' fragilities.

${ }^{4}$ Interview in February 2016. Some of its content can be read at http://fuentelatina.org/el-judio-que-hasalvado-a-los-yazidis/
} 
He explains he uses money solely to pay the so-called strugglers - the Iraqi men who actually rescue women and girls from captivity. Whether it is correct or not is not the aim of this article. However, it was important to quote this rescue strategy as an example of action to save Yezidis that has nothing to do with governmental procedures.

Through his organization, CYCI, Steve Maman let the world know there was a way to save women and girls who were captured as slaves and it brought two consequences: rescue prices went up, making it more difficult to save Yezidis; but, on the other hand, it let the world know some enslaved women and girls were being rescued and, as free people, they were able to share their testimonies with the world.

Last year, many newspapers and newscasts started writing stories on girls who were treated as slaves and some of them allowed reporters to record interviews. Those testimonies were important to confirm the revival of slavery in 21 th century.

Despite all reports and testimonies, only a few months ago, in March $15^{\text {th }}$ 2016, United States finally recognized the genocide against Yezidi people in Syria and Iraq - not only regarding women and girls, but also men, as many of them have been deliberately executed every day.

This article focuses on the treatment received by women and girls who remain enslaved in dozens of buildings in Iraq and Syria. A study on how this perverse system works might help the academic community to raise awareness over the urgency of measures that effectively guarantee women's rights.

\section{Yezidi Religion}

Yezidi Religion has drawn the attention of many researches in the past years. Although several elements found in this religion derivate from an ancient Iranian faith, researchers haven't come to a conclusion over the origins of this Religion, as it has some features of Islamism, Zoroastrianism and the faith of Ahl-e Haqq ${ }^{5}$. The lack of consensus over Yezidism was widely studied by Philip G. Kreyenbroek in 1995.

Besides the difficulty to identify Yezidism' origins, Kreyenbroek (1995) also points out another challenge to understand it: the absence of a sacred book. Scholars found some religious texts, but evidences proved Yezidism is a non-literate religion and this feature makes Yezidism different from other religions before the eyes of Islamic State ${ }^{6}$.

The Yezidi tradition can only be understood as the product of a long period of oral transmission. The lack of a written tradition has, as we saw, prevented the development

\footnotetext{
${ }^{5}$ Ahl-e Haqq is a cult probably originated among Western Iranians in which people believe some nature elements such as water, air, fire and earth must be respected because they are signs of god.

${ }^{6}$ One of the reasons presented by Islamic State to persecute Yezidis is the absence of a sacred book. Some reports have shown that for Christians and Jews - Religions that follow a sacred book - IS usually give them the chance to pay a fee to live when they don't want to convert themselves to Islamism. This option is not offered to Yezidis, which shall die if they do not convert to Islamism. Therefore, the absence of a sacred book may be one of the reasons used by IS to justify its efforts to eradicate Yezidis.
} 
of a formal theology, or the emergency of a single, monolithic system of beliefs. (Kreyenbroek, 1995: 19)

Another feature of Yezidism that has been frequently used as a justification to its followers' persecution is the fact they worship not only God, but also a figure known as Tamusi Malak, which is the Angel Peacock created by God prior to the world's inception - this worship has historically been misunderstood as devil's devotion. In fact, Orthodox Muslims believe this angel is Satan itself, hence, according to them, Yezidis don't deserve the protection of Islamic law as they are considered Satan's devotees. This might explain why followers of Orthodox Islam have persecuted Yezidis since $1.442^{7}$, when one of Persian theologians named Jalāl alDīn Muhammad ibn 'Izz al-Dīn Yūsuf al-Hulwānī ordered the killing of a large number of Sheikh Adī’s followers in the Kurdish Hakkarī Mountains ${ }^{8}$.

Despite the absence of a sacred book, some Yezidi precepts can be found in two documents (one made by the Ottoman government in 1872 - and another made in 1908 as a request of Armenian Yezidis) ${ }^{9}$. Here are some of their main points (Kreyenbroek, 1995):

- Every member of the sect must visit the shrine of Sheykh Adī every year.

- Every member must go to a place to see the rising sun where there is no Muslims, Jews or Christians.

- Yezidis must avoid dark blue clothes

- Yezidis cannot enter a closet, go into a public bath, and eat with the spoon of a Muslim.

- Yezidis believe in one God.

- Yezidis does not have a scripture.

- It is forbidden to have relations with people from different countries.

- Yezidis must build schools so as to instruct children in science and language.

\section{Sex Slavery justifications}

As highlighted before, the misunderstanding over the Yezidis worship in Tamusi Malak dates back to the origins of Yezidism and some documents have evidences that Orthodox Muslims have historically persecuted Yezidis.

\footnotetext{
${ }^{7}$ It can be deducted that the persecution against Yezidis is historical. Orthodox Muslims never accepted their existence as they believe Yezidis are Satan's devotees. Hence, the appearance of Islamic State increased hate to a level in which extremists believe Yezidis don't deserve to live.

${ }^{8}$ Sheykh Adī is one of the most important figures of Yezidism, which is why his tomb is a place of pilgrimage. As other scholars, Kreyenbroek considers him one of the key persons that enabled the emergence of Yezidism. He was born in 1073 or 1078, had Sufi training in Iraq and gained the reputation of mystic. Many people decided to follow him in the Hakkari Mountains, Northern Iraq, and he soon became famous. He died in 1160 or 1162 (Kreyenbroek, 1995).

${ }^{9}$ The first document is known as "the 1872 Petition" and was made to exempt the Yezidis from military service. The second document was written by a Yezidi in order to revitalize the community, mainly in other countries.
} 
Currently, this persecution reappeared with Islamic State, which has released flyers teaching people how they can recognize a Yezidi so as to treat them different from people from other Religions such as Catholic and Jew. This differentiation becomes particularly clear if we read the fourth edition of the group's online magazine, Dabiq:

Their continual existence to this day is a matter that Muslims should question as they
will be asked about it on Judgment Day (...) kill the mushrikīn wherever you find
them, and capture them, and besiege them, and sit and wait for them at every place of
ambush. (...) The Yazidis present-day creed - as it has changed over history - entails
the worship of Iblīs who they consider to be a fallen but forgiven angel amongst
the angels who were ordered to prostrate to Ādam! (...) Their creed is so deviant
from the truth that even cross-worshipping Christians for ages considered them devil
worshippers and Satanists, as is recorded in accounts of Westerners and Orientalists
who encountered them or studied them. (Dabiq, 2014)

Unlike the Jews and Christians, there was no room for jizyah payment. Also, their women could be enslaved unlike female apostates who the majority of the fuqahā say cannot be enslaved. (Dabiq, 2014)

One should remember that enslaving the families of the kuffār and taking their women as concubines is a firmly established aspect of the Shari' ah that if one were to deny or mock, he would be denying or mocking the verses of the Qur'ān and the narrations of the Prophet (Dabiq, 2014)

Despite the fact that Yezidi women and girls are the most targeted group to be enslaved, there are also reports of other minorities that have been captured and sold in slavery market. ${ }^{10}$

It is believed that in order to establish the sex slavery system, Islamic State released a pamphlet with some rules (always quoting the Qur'ran) to be followed by its soldiers and supporters regarding sexual slavery. By way of knowledge here are some of its points: it is permitted to have sexual intercourse with a female captive if she is not virgin (in this case, her uterus must be previously purified) and even if she has not reached puberty (in this case, it is advisable to see if the girl fits for intercourse, but the pamphlet doesn't mention any limit age); it is also permitted to buy, sell or give the slaves as gift because they're merely property (in their own words) ${ }^{11}$.

There are many evidences of young girls who have been raped by IS soldiers, indicating the concept of "fitting to sexual intercourse" seems to be only a matter of opinion.

The Sweden scholar Martina Johansson investigated the use of sexual violence by Islamic State since August, 2014. Through a qualitative method, using official documents that provide

\footnotetext{
${ }^{10}$ Some reports from organizations dedicated to releasing Yezidis from captivity have spoken of Christian women and girls that have remained in the hands of Islamic State as sexual slaves. Nevertheless, they seem to represent a small number if compared to Yezidi slaves.

${ }^{11}$ The pamphlet's full content can be found at Free Yezidi Foundation's website: https://www.freeyezidi. org/what-is-happening-to-the-yezidi-people/
} 
information on what IS has been doing to Yezidi women and girls, she tried to find reasons used by extremist groups to legitimate sexual violence. In her thesis, she identified at least three explanations: a religious one; a process to humiliate and intimidate Yezidi women and girls as to make them fell worthless; and a way to confirm the soldiers' masculinity - a common practice in conflict areas. Johansson (2015: 7) worked with this three possible explanations to the IS usage of sexual violence.

All those three possible justifications seem to play an important role in the construction of the sexual slavery system. Religion is used to legitimate the practice among soldiers and IS supporters. Many women's testimonies describe men praying before raping them and devoting this kind of rape (particularly referring to Yezidi women and girls) to God.

The humiliation and intimidation component is important to avoid Yezidi reactions, inflicting fear. And fear is known as an important tool used by terrorists, including those ones who swore loyalty to Islamic State. La Corte (2007) focused on the psychosocial approach to explain the usage of violence to instill fear.

The spreading of fear or terror through violence has a communicative dimension. Remember the relationship between terrorism and propaganda: after all, terrorist violence is a means to direct people's attention to certain problems (real, exaggerated or fictitious) and publicize the terrorist's political or religious demands (La Corte, 2007: 2)

Regarding sexual violence - especially the sexual slavery market - propaganda has seem to be used targeting national citizens, that is, reports and advertises seem to focus on IS soldiers, supporters and potential fighters (that used to live abroad and abandon their homes to join Islamic State in Syria and Iraq). This hypothesis may be true due to the relatively absence of slavery videos released by ISIS in the Internet, whereas mass executions and decapitations are widely disseminated in the Internet.

The third component studied by Johansson (2015: 9) is associated with masculinity concept and may be labeled as a universal explanation to the usage of violence against women in wartime since practically in all humankind's conflicts, there were indications of women raped and used as weapon of war.

In view of these three possible explanations to IS violence against women it can be inferred that all of them have played an important role in the establishment of the slavery market in Iraq and Syria. As Johansson concluded:

The findings in this thesis suggest that the sexual violence committed by ISIL against women and girls can be explained as weapon of war and has a strategic function in targeting the Yezidis. And the underlying reason for this is ISIL's religious doctrine, which permits and encourages them to use sexual violence against non-Muslim women and girls ${ }^{12}$. (Johansson, 2015: 28)

\footnotetext{
${ }^{12}$ Despite the fact that are some evidences of rapes of non-Muslim women and girls (not only Yezidis), reports made by many official organizations such as UN, Human Rights Watch and Amnesty International have shown that Yezidi women and girls are the most targeted group to be enslaved.
} 
artigo

\section{Historical approach of sex slavery}

Victims' testimonies have left humankind shocked by the cruelty used by IS against Yezidi women and girls in the markets. A place where IS supporters buy and sell Yezidi women as goods.

Unfortunately, there is nothing new in trading human beings - including, for sex - as stated by Brooten (2010: 3):

Slavery as a legal institution has existed for most of recorded history and was allowed by Jewish, Christian, and Islamic sacred texts, traditions and religious law. The forms of slavery varied considerably but shared the underlying concept of owning a human body. That concept has had a profound impact on Jewish, Christian and Islamic thinking about sexuality and about marriage between women and men.

The professor of Christian's studies at Brandeis University, Bernadette Brooten, provides historical information on this issue in one of her researches, presenting evidences that slavery including sexual slavery - might date back from the time of ancient Israelites and was, later, spread to the new World. In fact, the researcher defends that sexual slope has always played an important role in slavery history.

Regarding religious justifications to sex slavery, many scholars have found documents that confirm Christians, Jews and Muslims supported this practice in old times and, in some cases, they even encouraged it. One of these examples can be found in Brooten's book (2010: 6), where she quotes one instruction regarding this issue signed by Pope Pius IX in 1866:

Slavery itself, considered as such in its essential nature, it is not all contrary to the natural and divine law, and there can be several just titles of slavery... It is not contrary to the natural and divine law for a slave to be sold, bought, exchanged or given ${ }^{13}$.

Explanations for slavery are also found in the Qur'an as early Islamic jurists allowed male slaveholders to have sex with their slaves (Brooten, 2010:11): “...who abstain from sex, except with those joined to them in the marriage bond, or (the captives) whom their right hands possess..." (Qur'an 23: 5-6)

The verses above are, indeed, very used nowadays by Islamic State to explain the revival of sex slavery.

\section{Islamic State's sexual slave market}

In the light of constructivist theory, which considers the impact of rules and norms in social behavior, it is important to present some empirical evidences of how IS sexual slave market works in Iraq so as to try to understand how Yezidi people have coped with it and why

${ }^{13}$ Instruction of the Holy Office, June, 20, 1866, signed by Pope Pius IX, cited by John Francis Maxwell, "The Development of Catholic Doctrine Concerning Slavery", World jurist 11 (1969-1970) 306-307 
global authorities seem to have been doing little to extinguish it.

As Islamic State was advancing in his aim of creating a Caliphate, it created some rules that must be followed by people who live in areas IS has conquered: some of them are applied to thieves, others to Christians who accepts to pay a fee so as to not convert to Islam and there are some specific rules to slaves. These rules seem to have changed dramatically the way of life of thousands people who remain under the power of the extremist Sunni group, which is why the constructivist approach seems to be the most appropriated to help understanding the impact of a specific rule - the permission of slavery - in the behavior of a whole community. Currently many scholars tend to use the constructivist theory while studying extremists' action because it considers the importance of the ideological factor as stated by David Schild (2011: 16):

\begin{abstract}
Neo-realism, is wholly unable to account for the rise to prominence of ideologicallydriven, non-utilitarian transnational terrorist activity - military action (supposedly the realm of neo-realist analysis) taken by a non-state entity (unconstrained by a power hierarchy necessitated by anarchy) against a state entity with no strategic benefit inherent in the act (an act that is an end in itself, devoid of security enhancement) ${ }^{14}$.
\end{abstract}

Sexual slavery system appears to be an end in itself - not a mean to conquer more territories, through a military perspective. Therefore, ideological factor plays an important role in this matter and has to been taken into account as it is necessary to convince its supporters to buy slaves and to show Yezidi women and girls that if they don't obey their owners, they'll be punished.

Official reports, articles written by local journalists in Syria and Iraq, as well as interviews with people directly involved in rescue operations of Yezidis provide some information to start studying the sexual slave market established by Islamic State. After careful review of this material it was possible to infer that this sexual slave market seems to have been introduced in August, 2014 when IS took over Mount Sinjar, in Northern Iraq. On Skype, Pari Ibrahim (cofounder of Free Yezidi Organization), described what happened there.

\begin{abstract}
In the morning people were fleeing from ISIS and family members were saying they were killing men and taking women and girls to sell them as sex slaves in markets in Raqqa, Syria, and Mosul, Iraq. And we heard that they were checking children under their arm - the young boys - if they had "hair", they would shoot them immediately. If they didn't have any hair under their armpits, they would use these children, young boys, to train them and brain wash into ISIS fighters or suicide bombers. The boys that were too old were killed immediately and men were also killed. And young women were taken as sex slaves and the women that were too old to be sold as sex slaves, they were immediately killed. Too old is like really old women, I think above $35^{15}$.
\end{abstract}

\footnotetext{
${ }^{14}$ Although this quote focus on terrorist actions, it seemed appropriate here because the article is about a practice that was established by an extremist group that is recognized as terrorist by the international community. Neo-realism theory tend to have a military approach and to set aside the ideological influence in the international process. Regarding sexual slavery, coercion power is not only dictated by military sources, but mainly through ideological strategies, as the Islamic State uses Religion to justify its practice.

${ }^{15}$ Interview given to me in February 21 ${ }^{\text {st }}, 2016$, verbal information, Rio de Janeiro, Brazil, interview made through Skype.
} 
In the article ISIS Enshrines a Theology of Rape, the journalist Rikmini Callimachi moves forward in this study. She explains how dozens of women and girls were taken from Sinjar and transported to Mosul. According to her, they were forced to get into white buses with the windows closed with curtains so as to not allow them to see the road. Survivors' testimonies indicate IS soldiers used to put dozens of women and girls in the same bus and after around six hours they were forced to get into some buildings, such as the Galaxy Wedding Hall and one of Saddam Hussein's palace. She adds that in addition to Mosul, there are also reports indicating some women and girls were taken to elementary schools and municipal buildings in other Iraq cities such as Tal Afar, Solah, Ba'aj and Sinjar. As soon as they arrived there, IS fighters conducted a kind of census so as to identify the exact number of captives they were keeping in one particular place. Recent escapees say that when a slave is bought, her slaveholder receives a contract and if he sells her to another person, he needs to make a new contract, following the same model used for property transfers. The slave can be set free if her owner signs her freedom. There is one testimony of this in the latest Amnesty International report on sexual slavery in Iraq. One 13 year-old girl said:

He took me to his home and I slept in a room with his older wife while he slept in another room with his younger wife. The older wife was very nice to me. He said he had bought me because he felt sorry for me and wanted to send me and my little sister back to my family and indeed he did so (Amnesty International Report, 2014: 10)

In some cases, the soldiers' family doesn't agree with the slavery system, but is afraid of doing anything to help setting free the slave. Fear seems to have been deeply ingrained in people under the domain of Islamic State, which reinforces the theory that it has been used to avoid people's reactions against its rules and norms.

Reports made by Human Rights Watch, Amnesty International and OHCHR provide more information on the sex slavery system established in Iraq around August 3th, 2014 when IS took over the region of Sinjar. The scholar Martina Johansson compiled seven of these reports and analyzed at least eighty interviews with women that escaped from IS between 2014 and 2015 so as to try to understand why Islamic State has been using sexual violence against women and girls, mainly the Yezidi ones. Therefore, her study is an important source of details, with testimonies that confirm the extreme violence used by Islamic State and its supporters.

From 9:30 in the morning, men would come to buy girls to rape them. I saw in front of my eyes ISIS soldiers pulling hair, beating girls, and slamming the heads of anyone who resisted. They were like animals... Once they took the girls out, they would rape them and bring them back to exchange for new girls. The girl's ages ranged from 8 to 30 years... Only 20 girls remained in the end (Johansson, 2015: 25)

Many women confirm that girls from 8 to 12 years old have been raped as the only prohibition addressed to IS soldiers is to have sex with a pregnant slave. Some girls were treated with so much violence that their bodies couldn't bare it. The journalist Rukmini Callimachi 
interviewed a Yezidi woman who shared the household with a 12-year-old who was repeatedly raped:

He destroyed her body. She was badly infected. The fighter kept coming and asking me 'Why does she smell so bad?' And I said, she has an infection on the inside, you need to take care of her. (Callimachi, 2015: 4)

In some cases, women would rather die than being raped and, as a consequence, they committed suicide.

We were 21 girls in one room, two of them were very young, 10-12 years. One day we were given clothes that looked like dance costumes and were told to bathe and wear those clothes. Jilan killed herself in the bathroom. She cut her wrists and hanged herself. She was very beautiful. I think she knew that she was going to be taken away by a man and that is why she killed herself. (Amnesty International Report, 2014: 8)

Since August, 2014, the number of women and girls who managed to flee from Islamic State has increased and so has increased the number of testimonies confirming the trade of slaves, describing the violence and how soldiers and IS supporters have treated women and girls. In spite of offering valuable information on the operation of the sexual slave market, the reports mentioned above don't present any estimation of how many women and girls have fled until now, how many were raped, how many committed suicide. The only numbers we could access were those provided by Yezidi organizations, but they are only related to Yezidis, which appears to be the community most harmed by IS.

\section{What about human rights}

In the previous pages, it was explained that sex slavery is a practice that was justified by some religions in the past centuries and some of Qur'an verses have been used to justify the revival of this trade system in 21 th century. It's true that slavery in seventeenth and eighteenth century need to be studied in those contexts, where some human beings were considered worthless. However, how can researchers explain the failure of human rights defense in our days as authorities were not able to avoid the establishment of sex slavery system in Iraq in August, 2014?

Despite the sex slavery system implemented by Islamic State, some similar practices appeared in recent years. Just to enumerate some of them: there are records of thousands of Korean women who were kidnapped during Second World War to serve as concubines to Japanese soldiers; during Civil War in Guatemala (1960-1996), extreme violence was used against women, including mass rapes and sexual mutilation. These examples appear to be some variations of sex slavery as none of them seems to have had a manual dedicated to it as the Islamic State made - as a clear measure to conduct this kind of trade. 
If sexual slavery appears to arise once in a while in History, in spite of the existence of some international precepts that guarantee human rights, then, what would be the reasons for this sort of cyclic arisen?

In the study over the usage of women bodies in wartime, the student Beth Speake tried to explain it.

Historically, gender-based violence has been ignored and unpunished, implicitly condoned through the prevalent and widely held assumption that rape and sexual violence are an unavoidable and inevitable element of the conflict (IRIN, 2014). Moreover, despite the recent attention to the issue of gender-based violence, enforcement of human rights law and international human rights treaties, particularly those laws dealing with women's rights remains weak (McQuigg, 2007, p. 474) and gender-based violence continues to affect great swathes of the world's population. (Speake, 2012: 2)

After analyzing the extreme violence used against women in different conflicts in $20^{\text {th }}$ Century, Speake came to the conclusion that international norms that should guarantee human's right remain weak. In the field of International Relations, it would be possible to conduct a deep investigation over the reasons why norms dictated by United Nations, for instance, haven't been enough to avoid such violent actions.

In this sense, the constructivist scholar Martha Finnemore researched specifically the norms around humanitarian intervention, which can play an important role in conflict areas. She analyzed changes in some norms along History that have a straight impact in areas where human rights have not been respected. Through a historical approach, she explained the universal concept of humanity, as we currently know, was consolidated after slavery abolition in $19^{\text {th }}$ century.

The ways in which interveners identify with victims to determine who is an appropriate or compelling candidate for intervention, changed dramatically over the twentieth century as the "humanity" deserving protection by military intervention became universalized. The seeds of this change lie in the nineteenth century, however, with efforts to end slavery and the slave trade. With the abolition of slavery in the nineteenth century and decolonization in the twentieth, a new set of norms was consolidated that universalized "humanity". (Finnemore, 1996: 170)

Therefore, after slavery abolition and decolonization, all human beings started been considered worthy and some countries decided to intervene in situations where this right was not being respected. However, as the international measures to protect human's rights were moving forward, explanations to intervene became more and more diverse and started to undergo the approval of the United Nations, which sometimes make things difficult as it is not quite easy to please the five countries of Security Council.

The necessity of United Nations approval goes beyond humanitarian intervention. Following the multilateral approach that currently legitimates important decisions made by governments towards other nations, military actions also need UN's approval, which could have made it more difficult to put some strategies in practice against Islamic State. 
Another hypothesis to the apparently weakness of human rights defense would be the often changed definition of who is recognized as a human being and deserves humanitarian assistance - which is a concept that has changed over the history.

Humanitarian intervention is not new. It has, however, changed over time in some systemic and important ways. First, the definition of who qualifies as human and, therefore, as deserving of humanitarian protection by foreign governments has changed (Finnemore, 1996: 184).

Regarding the sexual slavery system established by Islamic State, this point seems to play an important role because, historically, central countries as United of States and some European countries have usually been willing to take more rapidly action in conflicts where its people are directly involved, which is not the case regarding sexual slavery in Iraq and Syria. In this matter, it is inevitable to raise the question: what would happen if some European or American women and girls were negotiated and raped? What is the difference between Yezidi women and the European ones? Unfortunately, History has proved that nations are usually not very concerned about thousands of people who are used to living with violence in conflict areas, especially in Africa. Their problem seems to only become a global issue when it makes victims in the West.

\section{Conclusion}

After all that was exposed in this article, one last thing needs to be highlighted. The Universal Declaration of Human Rights was firmed in December, 1948 and has one specific article referring to slavery: "No one shall be held in slavery or servitude; slavery and the slave trade shall be prohibited in all their forms" (UN, 1948). This document was signed in 1948. Nevertheless sixty eight years later, there are lots of reports of women and girls who have been treated as properties and have been sold and raped in Iraq and Syria.

Many scholars have been dedicating their time to understand how this cruel type of gender violence still happens but it seems that more study need to be done. In this article, some possible explanations were pointed out (such as the weakness of international laws; the need of UN approval to start a humanitarian intervention, which sometimes is harder to achieve and, as a consequence, the people under a conflict remains without assistance; the variable concept that qualifies who deserves humanitarian assistance).

In spite all of that, further researches need to be done not only to understand why a secular violent practice continues making victims, but also to help authorities and governments to find an effectively way to extinguish it, mainly the system established by the so-called Islamic State.

With more research, the academy may contribute to set free thousands of women that remain under extremists' hands and put an end to this violent practice that has never totally been banned. 
artigo

\section{References}

AMNESTY INTERNATIONAL. Escape from Hell: Torture and Sexual Slavery in Islamic State Captivity in Iraq, 2014. Available in: https://www.es.amnesty.org/uploads/media/ Escape_from_hell_- _ _Torture_and_sexual_slavery_in_Islamic_State_captivity_in_Iraq_-_ English.pdf Accessed on: May 2 ${ }^{\text {nd }}, 2016$.

BROOTEN, Bernadette. Beyond Slavery: Overcoming Its Religious and Sexual Legacies. New York: Palgrave Macmillan, 2010.

CALLIMACHI, Rukmini. ISIS Enshrines a Theology of Rape. Assyrian International News Agency, August, 2015. Available in: http://www.aina.org/news/20150813132827.htm Accessed on: April 2nd, 2016.

FINNEMORE, Martha. Constructing Norms of Humanitarian Intervention In: KATZENSTEIN, P. (org.) The Culture of National Security: Norms and Identity in World Politics. Ithaca: Cornell University Press, 1996. p. 153-185.

JOHANSSON, Martina. Wartime Sexual Violence: the case of Islamic State in Iraq and the Levant (ISIL), 2015. Available in: http://lup.lub.lu.se/luur/ download?func $=$ downloadFile \&recordOId=5468180\&fileOId=5468182 Accessed on: April 21th, 2016.

KREYENBROEK, Philip G. Yezidism - Its background observances and textual tradition. United of States: The Edwin Mellen Press, 1995.

LA CORTE, Luis de. Explaining Terrorism: A Psychosocial Approach, 2007. Available in: http://www.terrorismanalysts.com/pt/index.php/pot/article/view/8 Accessed on: March 18 ${ }^{\text {th }}, 2016$.

SCHILD, DAVID. Constructivism as a basis for understanding transnational terrorism: the case of Al Qaeda, 2011. Available in: http://ujdigispace.uj.ac.za/bitstream/ handle/10210/4228/Schild.pdf?sequence=3 Accessed on: June $26^{\text {th }}, 2016$.

SPEAKE, Beth. Women's Bodies are battlefields, 2012. Available in: http://www.e-ir. info/2012/04/25/womens-bodies-are-battlefields/ Accessed on: April 21th, 2016.

THE revival of slavery before the hour. Dabiq, $4^{\text {th }}$ Edition. October, 2014. Available in: https:// 
artigo

media.clarionproject.org/files/islamic-state/islamic-state-isis-magazine-Issue-4-thefailed-crusade.pdf Accessed on: March 15 2016.

UN General Assembly. Universal Declaration of Human Rights. 10th December, 1948.

Available in: http://www.un.org/en/universal-declaration-human-rights/

Accessed on: March 29 2016.

WHAT happened to the captured women and children. Free Yezidi Organization. Available in: https://www.freeyezidi.org/what-is-happening-to-the-yezidi-people/ Accessed on: March $29^{\text {th }}, 2016$. 